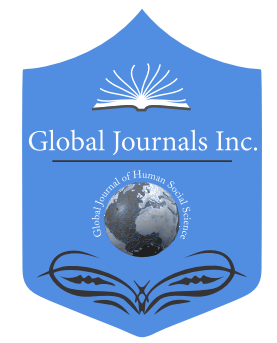

GLOBAL JOURNAL OF HUMAN-SOCIAL SCIENCE: B

GeOGRAPHY, GeO-SCIENCES, ENVIRONMENTAL SCIENCE \& DisASTER MANAGEMENT

Volume 20 Issue 4 Version 1.0 Year 2020

Type: Double Blind Peer Reviewed International Research Journal

Publisher: Global Journals

Online ISSN: 2249-460X \& Print ISSN: 0975-587X

\title{
Real Estate Market Prices and Floods in Rio Do Sul (Santa Catarina, Brazil): Evidences of Correlations under a Territorial Perspective
}

By Rodrigo Sartori Bogo, Eliézer Conceição \& Eduardo Longo

Federal University of Santa Catarina (UFSC)

Abstract- The city of Rio do Sul, State of Santa Catarina, Brazil, is marked since its colonization in the last years of the 19th century from frequent and intense floods that shaped its urbanization and relation of its residents with the environment. After the 1983 floods that reached the historical record of 13.56 meters over the riverbed and the 2011 events, the second-highest ever, researchers argued that the local, territorial dynamics of spatial segregation and real estate market changed and became attached to the floods quotas. However, none of them ever showed these conclusions by empirical data, what is the objective of this research. After collecting data from 200 terrain properties to sale on this city, the researchers applied geostatistical (specially kriging) and geoprocessing methods with Geographic Information Systems to identify if there is a relation of cause-effect with the different flood quotas reaching the properties with its market value. The results are that this association exists, but is not the only variable that explains value variations in Rio do Sul, with relevant weight from the city's centrality to real estate market prices.

Keywords: urban planning; spatial analysis; real estate market values; territorial relations; natural disasters.

GJHSS-B Classification: FOR Code: 040699

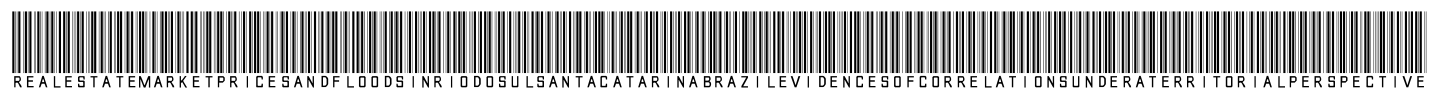

Strictly as per the compliance and regulations of:

(c) 2020. Rodrigo Sartori Bogo, Eliézer Conceição \& Eduardo Longo. This is a research/ review paper, distributed under the terms of the Creative Commons Attribution-Noncommercial 3.0 Unported License http://creativecommons.org/licenses/by-nc/3.0/), permitting all non-commercial use, distribution, and reproduction in any medium, provided the original work is properly cited. 


\title{
Real Estate Market Prices and Floods in Rio Do Sul (Santa Catarina, Brazil): Evidences of Correlations under a Territorial Perspective
}

\author{
Rodrigo Sartori Bogo ${ }^{\alpha}$, Eliézer Conceição ${ }^{\circ}$ \& Eduardo Longo ${ }^{\circ}$
}

\begin{abstract}
The city of Rio do Sul, State of Santa Catarina, Brazil, is marked since its colonization in the last years of the $19^{\text {th }}$ century from frequent and intense floods that shaped its urbanization and relation of its residents with the environment. After the 1983 floods that reached the historical record of 13.56 meters over the riverbed and the 2011 events, the second-highest ever, researchers argued that the local, territorial dynamics of spatial segregation and real estate market changed and became attached to the floods quotas. However, none of them ever showed these conclusions by empirical data, what is the objective of this research. After collecting data from 200 terrain properties to sale on this city, the researchers applied geostatistical (specially kriging) and geoprocessing methods with Geographic Information Systems to identify if there is a relation of cause-effect with the different flood quotas reaching the properties with its market value. The results are that this association exists, but is not the only variable that explains value variations in Rio do Sul, with relevant weight from the city's centrality to real estate market prices. However, the premise is true for the neighborhoods far
\end{abstract}

away from the city center, where the lowest prices are in floodable places. In the same analysis, the researchers identified that the highest values are from properties free from floods and close to the central area, but not widely enough to confirm the hypothesis, considering its methodological limits.

Keywords: urban planning; spatial analysis; real estate market values; territorial relations; natural disasters.

\section{InTRODUCTION}

I he Rio do Sul municipality location (Picture 01) is in the region known as Alto Vale do Itajaí (Itajaís High Valley, in a free translation), at Santa Catarina state, southern Brazil. Its territorial limits are with the municipalities of Agronômica, Lontras, Laurentino, Presidente Getúllio, Ibirama, and Aurora, totalizing an area of 260,82 square kilometers, with an estimated population of 70 thousand inhabitants (IBGE, 2019).

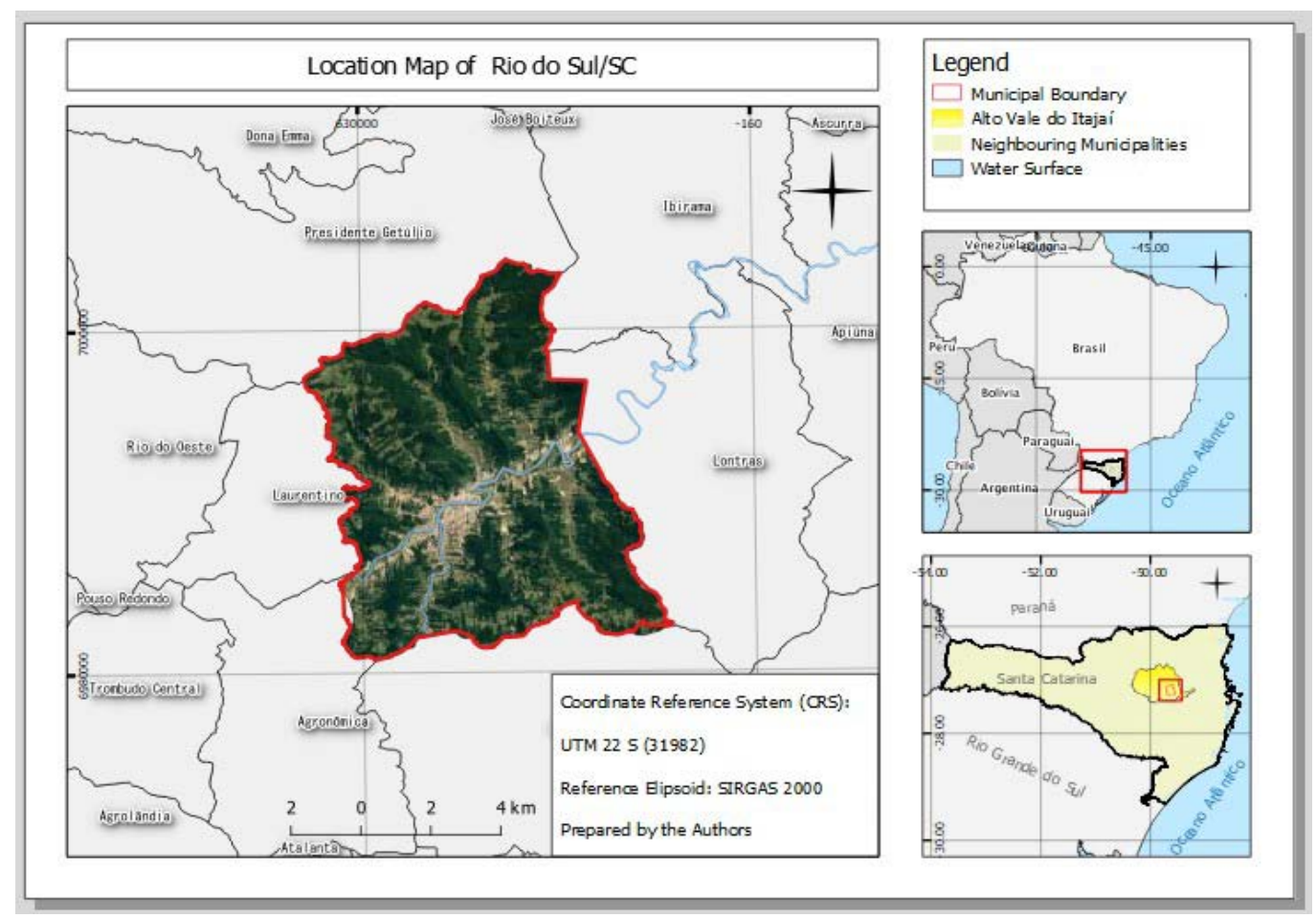

Picture 01: Location map of Rio do Sul/SC municipality

Author $\alpha$ : Bachelor and licensed in Geography. Master in Geography on the Federal University of Santa Catarina (UFSC). e-mail:RSbogo@gmail.com

Author б: Bachelor and licensed in Geography. Master in Civil Engineering on UFSC. e-mail: eliezerconceica@gmail.com Author p: Lawyer, Master and doctoral student in Territorial Planning and Socio-Environmental Development.

e-mail: eduardosl.geo@gmail.com 
The city has a past and present of urban floods that, in historical terms were also responsible for reflecting in its urban development characteristics, concomitantly interfering in its territorial relations and real estate market prices dynamics (COLAÇO \& KLANOVICZ, 1999; ESPÍNDOLA \& NODARI, 2015; BOGO, 2020).

With the knowledge about its geographical characteristics and its socio-spatial formation, this research sought to analyze, with data collected from real estate market values, how the realty prices fluctuate according to some aspects. In this matter, we tried to understand how the variables (a) flood occurrence risk, (b) altitude/relief (that also determines the flood risk) and (c) urban centrality (what has relevant aspects such as better infrastructure, commerce flows and, services being a variable that interferes in real estate market values) can influence land values and economic segregation in this urban space.

Therefore, from the use of geoprocessing technics and its methods of data manipulation and visualization, the researchers realized kriging processes and made cartographical products that sought to provide a better understanding and interpretation of this case of study.

\section{The Rio Do Sul's Floods and its Relations With URBanization}

Whenever we treat about a study object that demands the use of the geographical science's principles, the two dimensions that compose must be present, being at a minimum stage contextualized in a way to understand the reality to be discussed and analyzed. As widely described by Massey (2005), these two dimensions are time and space, that must be understood together in every scientific investigation that applies the presets of Geography, composing the researchers "mind", as the author stated in a posterior paper (MASSEY, 2017).

So, this is valid also to study cities and their dynamics, with its variable scales (from small municipality centers to global megalopolis). Understanding its spatial and temporal processes that are part of wider national and regional socio-spatial formations are needed aspects for the urban studies, even when only for contextualization, as presented here.

In consequence, the Brazilian urban space is full of heterogeneous phenomena that vary regionally and according to the temporal processes that compose them. Even if the common sense thinking establishes that Brazilian cities never had any kind of urban planning, we know that a lot of nodal points that became urbanization cores were deliberately chosen with strategic purposes, accompanied by pre-made urban designs, representing each historical context and ideological zeitgeist of the governors from each period.
This is real for cities of large dimensions as Salvador, Aracaju, Macapá, Belo Horizonte, Goiânia, Brasília, and Palmas, among others; for the territorial occupation by small and medium-sized cities in the Centro-Oeste (midwest) and Norte (north) regions of the country; and also for the planned cities promoted by private institutions like industrial ones (Volta Redonda and Ipatinga, for example) or created by colonization companies (like the Londrina and Maringá region, in Paraná state's north) (VILLAÇA, 2019).

However, as argued by the same author, these spatial acts previously planned and executed in the territory, such as infrastructure maintenance and the population needs didn't characterize by it some kind of national or even regional urban planning. Still, only punctual interventions and projects, without an effective integration or realization of long or very long term planning ${ }^{1}$. Some consequences of this effect were the lack of thinking about the metropolitan reality that would become the norm in Brazil (over the municipality chambers) and the own disorderly growing of cities, in other scales.

According to Santos (2013) analysis, Brazil, predominantly rural until half of the 20th century, had internal migrations that had never occurred before and passed through a demographical explosion in the big cities $^{2}$, that became the focal point of a wide range of social phenomena of Brazilian space, with spotlight to social-spatial inequalities. This ends up overlapping with other urban problems and turns to evidence the different accesses to amenities from certain demographic groups. As a consequence of these inequalities, that occur especially from the territorialities practiced from spatial agents such as the Estate or the private market (like the real estate one) (CORRÊA, 1986), factors that involve the relation between marginalized populations and the environment tend to become costly for both sides: the human occupation is made in inadequate and polluting ways, interfering in its quality of life, and in the same time different ecosystems suffer from unregulated interference (DE PAULA, 2015).

As discussed before, the urban phenomena that occur in Brazil are consequences of its socialspatial reality, but manifest itself differently in each specific context, being in regional or local scales. As argued by Tucci (2007), there is an intense relationship between urban settlements in Brazil and the rivers that compose the country, being in the surroundings of river sources, valleys, or mouths, especially in coastal cities. Goularti Filho (2014) considers this phenomenon as

\footnotetext{
${ }^{1}$ As characterized by Souza (2010), urban planning must treat about long or very long periods, differently from the urban management, focused on short or medium prompts.

2 Process that already occurred starting on the 1930 decade but became more intense with the centralization tradition imposed by the civil-military dictatorship that ruled in Brazil between the 1960 and 1980 decades (VILLAÇA, 1999.)
} 
natural for the colonization and urban network consolidation processes since the rivers can be a source of potentially drinkable water, irrigation, energy generation, effluent discharge and, commodities and, people transportations. According to the author, this is notably strong in the Brazilian case since there is a huge hydrological network in most regions, excluding the dry northeast (that has the São Francisco basin, with high flow competence).

However, Grangeiro, Ribeiro \& Miranda (2020) shows that this dynamic had (and still has) direct consequences on these cities urban planning and in the quality of life of its inhabitants, composing an unsustainable relation, resulted from the disorganized growing of urban spaces and the absence of integrated urban management. The authors criticize the public administration structure about themes evolving the urbanizations around the rivers in Brazilian reality. So, it is a context that there is no proper metropolitan management to deal with the urban conurbations that exist in urban centers of variable dimensions (as argued by Souza [2010] and Santos Júnior \& Montandon [2011]), together with the segmentation of civil defense among the municipalities and the low deliberative capacity of the Agência Nacional de Águas (National Agency of Waters, in a free translation) hydrological basins committees, managements scale that could raise the quality of the above-mentioned scenario.

This isn't different for Santa Catarina state, where is located the municipality discussed here. This city has historical variations on the development of its regions, either by different forms of territory occupation and land use $^{3}$, either by the significant environmental conditions, expressed especially by the local geomorphology, that impacted the occupation and dispersion models on the territory. However, considering the differences, Maar, Peron \& Netto (2011) and Goularti Filho (2014) show the importance that the hydrological basins had to the colonization, production and, capital accumulation on the geographical space of Santa Catarina, on all its regions.

However, the Itajaí-Açu river valley, the biggest basin entirely in the state (SANTA CATARINA, 1986), receives a special spotlight for its dimensions and relatively huge urban network that formed there. Some of the most populous and economically relevant cities are on its stream way, forming dense and dynamic population cores, that maintain direct relations with other centers of higher dimensions of the country, like Florianópolis, Curitiba and São Paulo (SIEBERT, 1997; IBGE, 2020). Analyzing from a hypothetical longitudinal line from the coast to west, there are three regional

\footnotetext{
3 A classic example is the difference between the subsistence occupation that started with the Azoreans on the coast, the large farms model of the uplands and the characteristically small properties of European colonization in the South, West and Vale do Itajaí regions (GOULARTI FILHO, 2014)
}

divisions: first, the river's mouth region, that has the Itajai city as its center. This city ${ }^{4}$, with an estimated population of almost 220 thousand inhabitants, $6^{\circ}$ most populous of the state has its most important port and is the center of an urban conurbation that includes of economically and demographically relevant municipalities, such as Balneário Camboriú, Itapema, Camboriú e Navegantes, among others (IBGE, 2019; 2020).

After, distant a little bit more than $40 \mathrm{~km}$ to the west, in the river's midway, there is the city of Blumenau, the first point of the valley's colonization by European immigrants and today the third most populous Santa Catarina municipality (almost 360 thousand inhabitants), being a regional core of textile industry and services with relevant dimension and center of a conurbation that extends itself to others cities like Indaial, Gaspar, Timbó e Pomerode. On its surroundings, still forming what is known as "Médio Vale"5 (Intermediate Valley, in a free translation) is the city of Brusque, with its urbanization around the Itajaí-Mirim river (Itajaí-Açu's affluent), today has more than 130 thousand inhabitants, $12^{\circ}$ most populous of Santa Catarina, that specialized itself also in the textile industry, presenting integration (and also dependency) with both the above-mentioned urban centers (GOULARTI FILHO, 2014; IBGE, 2019; 2020).

Finishing the regional divisions, about $70 \mathrm{~km}$ to the west relatively to Blumenau, we find the third "region" that forms the Itajaí-Açu's hydrological basin, known as Alto Vale and has as its "capital" the municipality of Rio do Sul. This city, emancipated in 1930, formed its urbanization around the junction between the Itajai do Oeste and Açú rivers (located at 337 meters above sea level), what Colaço \& Klanovicz (1999) call its "structural node". Today with about 70 thousand inhabitants and conurbated in different levels with the municipalities of Agronômica, Lontras, Aurora e Laurentino, it became an industrial and services core for a region composed of around 30 municipalities, besides still being dependent of bigger centers such as Florianópolis and Blumenau (IBGE, 2019; 2020).

What the above paragraphs show is that the urban network that developed on this hydrological basin is historical and geographically dependent on its major rivers, with the urban center of relevant density located specially on its flood plains or the hills around them. There is, therefore, a combination of disorganized space occupation and natural dynamics that generates a context where there is a high susceptibility to environmental disasters. This factor, present in most of the state, something showed by the researches of Maar, Peron \& Netto (2011) and Nodari, Espíndola \& Lopes (2015), intensifies itself even more in the Vale do Itajaí,

\footnotetext{
${ }^{4}$ According to the IBGE (2020), in terms of urban influence, Itajaí connects itself to Balneário Camboriú, forming an urban binary that is one of the main state centralities.

${ }^{5}$ This is the very well-known name beside the city's center being only 16 meters above sea level.
} 
by the correlation between anthropic elements and regional environmental conditions, like rain indexes, rock substratum, soils types, river dynamics, among others (DE PAULA, 2015; BOGO, 2020).

Discussing specifically Rio do Sul, part of the above-mentioned context and target of this research, it's possible to understand that its position isn't different from the regional norm, knowing that the spatial agents as the private sector, the State and the own civil society (regarding urbanization, considering migrations and self-building) generated interventions without territorial ordering in an unsustainable way, being the environment only a resource provider.

In institutional terms, it is well known from researches in the urban planning field that the making, approving and, application processes of the local participatory master plan (PMP) took too much time to be made and also hit low-quality standards. As described by authors like Poleza (2013), Lapolli (2013) and specially Bogo (2016, 2019, 2020), some general characteristics were identified about to two master plans presented since the publication of the Estatuto da Cidade (Cities Statute, in a free translation) law, being these published in 2006 and 2014: composition process made "by the book" not following the local needs, especially the 2006 edition, approved close to the deadline established by the federal law; low level of participation and distribution through the local population, that had minimal interference in its production; besides the technocratic model, the own municipality chamber dedicated lack of resources and funds to the PMP, made by a small group of its employees; and, the most relevant factor, both planning documents were not restrictive to urbanization in risk areas and almost didn't consider the city's relation with the floods, with minimal interference in the established reality.

But, after all, why the criticism of the lastmentioned element above is so relevant to the case of Rio do Sul? Because the city presents a long record of relation with urban floods that, in a dialectic understanding, were influenced by its urbanization at the same time that shaped it, interfering the territorial dynamics that happen there (COLAÇO \& KLANOVICZ, 1999; ESPÍNDOLA \& NODARI, 2015; BOGO, 2020). With colonization made by Europeans that began at the $19^{\text {th }}$-century end, becoming a municipality in 1930, the whole urbanization process and the anthropization escalation ${ }^{6}$, occurred on the Itajaí-Açu's river flood plains or on the hills surrounding it, according to the norm for the biggest cities that form Vale do Itajaís urban network.

\footnotetext{
${ }^{6}$ The effects resulted were the river's silting up, impermeability raise, riparian forest deforestation and margins occupation (ESPÍNDOLA \& NODARI, 2015).
}

However, the parallels between the natural river floods and the human occupation on its surroundings are notably strong for this city and date back to before its foundation as a municipality. From historical records of the Municipal Chamber of Rio do Sul (PMRS, 2019) and from researchers such as Colaço \& Klanovicz (1999) e Espíndola \& Nodari (2015), we know that intense flood events already happened in the 19th century's end ${ }^{7}$, as well as on 1910, 1930 and, 1950 decades. However, this wasn't enough to stop the local economy and demographical growth that reached prosperity with the timber industry that reigned over most state regions between the 1950 and 1970 decades (GOULARTI FILHO, 2014; ESPÍNDOLA \& NODARI, 2015; BOGO, 2016).

This fact takes us to the 1980s, when the population was already almost entirely urban, while the economy was showing clear signs of weakness, as results from the confluence between national economic crisis and restrictions to the wood cutting, then the major local source of economic goods. At this moment, there wasn't any relevant flood since 1958, which intensified the urbanization around the river, with permission from the municipal chamber government (COLAÇO \& KLANOVICZ, 1999; ESPÍNDOLA \& NODARI, 2015).

It is in this context that occurred the 1983 floods, hitting 13.58 meters over the riverbed, highest ever recorded in the city's history (PMRS, 2019), causing ruinous consequences in social and economic terms by reaching about $80 \%$ of the population and $95 \%$ of the industries. Beyond the material damages, this event became a historical symbolic mark for the locals and became a source for news even for the national media. After this event, an already weakened community and recovering from what happened the year before suffered again with the 1984 floods that, even though smaller ${ }^{8}$ than the 1983 one, it caused unprecedented impacts to the cities and its inhabitants (POLEZA, 2003; ESPÍNDOLA \& NODARI, 2015). The following map (Picture 02) exposes the municipality's topography and its relation with the river.

\footnotetext{
7 This fact also happens in Blumenau, with colonization that started before and, located down the river basin (DE PAULA, 2015).

8 The flood quota was of 12.80 meters (PMRS, 2019).
} 


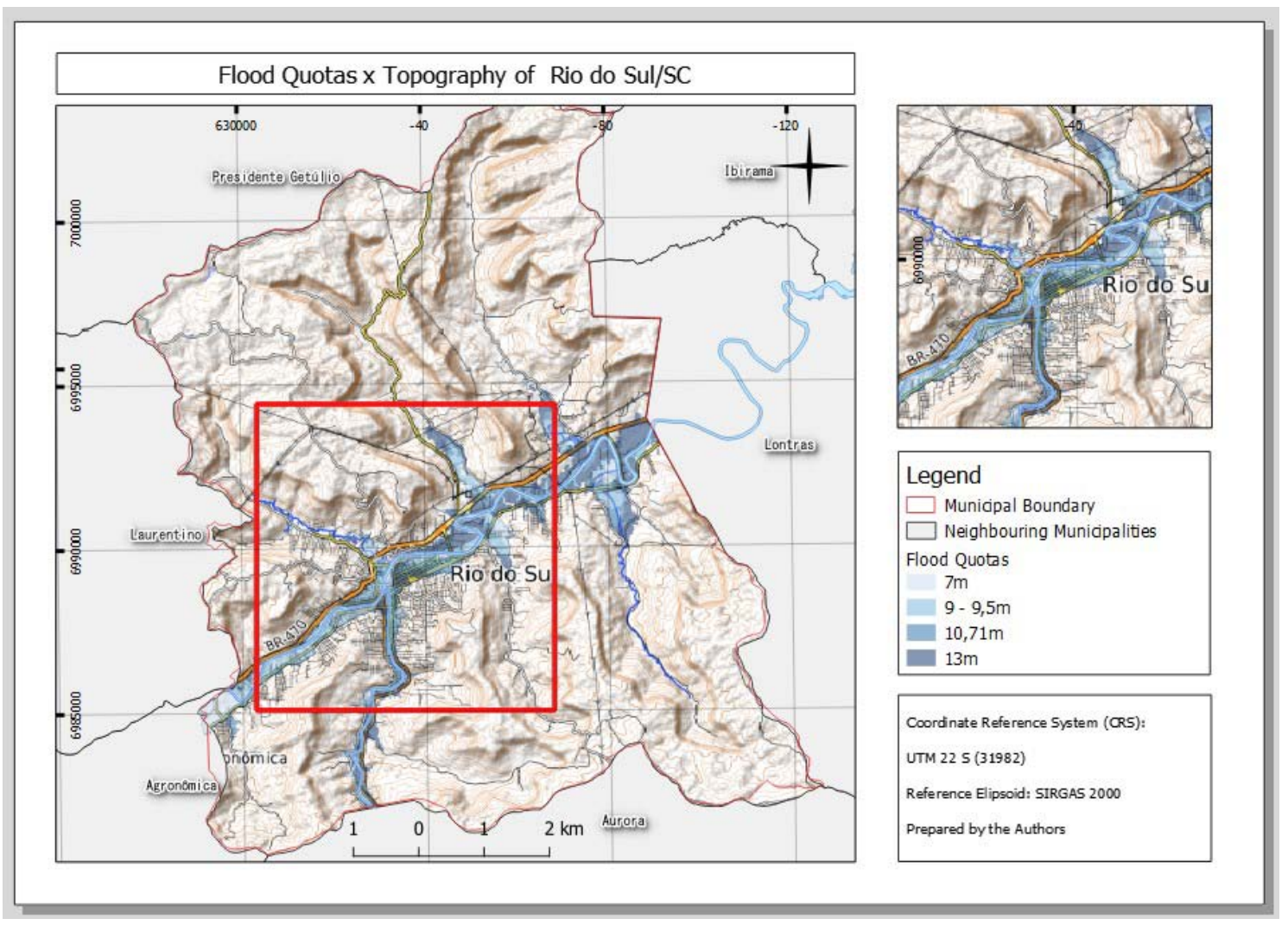

Source: By the authors

\section{Picture 02: Flood quotas and topography of Rio do Sul- SC}

But, as argued by Lapolli (2013), another 25 years passed without huge floods that, together with the already established economic grounds, allowed Rio do Sul another period of growth, becoming a regional center focused on industries and services, being among the top 20 economies in the state and one of the best cities of Santa Catarina to live in terms of quality of life. However, these facts didn't prevent the 2011 floods that reached 12.56 meters above the riverbed $\left(2^{\circ}\right.$ highest ever), causing massive material and social prejudices again, with estimated values of $\mathrm{R} \$ 283$ million $^{9}$. Beyond that, this occasion was marked by criticism about the public power (municipal chamber and civil defense) inoperability in reference of preventing and managing the disasters (BOGO, 2016; 2020).

Differently of other huge flood events, that weren't or had just one following new consecutive occurrence (like the 1983-1984 cases), the 2010 decade marked the city for the atypical happening of floods, probably a result of more intense and unregulated raining combined with space anthropization. Besides 2011, other huge floods ${ }^{10}$ happened in 2013, 2015 and, 2017, turning the already severe city's relation with environmental disasters in something even worse

\footnotetext{
${ }^{9}$ Close to 168.5 million US dollars at the time.

${ }^{10}$ It is also important to take note about the small scale floods that happen with more frequency and reach areas closer to the river, normally occupied by lower standards buildings (BOGO, 2019).
}

(BOGO, 2020). With this scenario, there is a question about the city's territorial relations and the public power's role: in which degree the more frequent floods (in different scales) interfere in the real estate market prices? To answer it is this research goal.

The process of land use devaluation of floodable areas that causes socio-spatial segregation insofar as the frequent urban floods turn the areas that are free of these disasters overvalued was already identified by other researches, something evident on the following citation

In Rio do Sul, it is possible to identify, in the last years, by the buildings and by the real estate market, the displacement of urban activities toward the higher areas, after its initial installation. This happened, especially, after the 1983/1984 floods, that changed the city's urban scenario deeply, inducing the opening of a lot of new neighborhoods and demographic transferences from upper areas to the lower and viceversa. In general, the members of wealthier classes transferred themselves to upper areas, free from the floods, occurring the inverse with populations of lower-income. [...] So it is impossible to, in current days, work with construction in Rio do Sul not considering the floods as a variable. The possibility or not of a flood reaching a building redefines the form of volumetric and its market value. [...] The floods were always perceived as a serious problem, event that 
they affect, more directly, the residents of lower quotas, where people with lower incomes are living.

\section{(ESPÍNDOLA \& NODARI, 2015, 74-76 pp.)}

However, the above-mentioned authors and others that point the same phenomenon, as Colaço \& Klanovicz (1999) e Bogo (2019; 2020) didn't show empirical evidence that there are spatial differences between higher and lower-income groups because of the floods in Rio do Sul ${ }^{11}$. We believe that this phenomenon occurs in this city, being considered as this research hypothesis. To test it, we build a methodology focused on geostatistics and the use of geographical information systems (GIS), from the real estate data compilation and its prices.

\section{ili. Collection And Discussions about Rio Do Sul's Real Estate Market Data}

This research sought to define, from the already known knowledge about the spatial frame discussed here, that it is possible to obtain evidence to show if there is spatial and economic segregation happening from some correlation with the urban floods upon the application of geoprocessing tools and methods.

The ground is, has been and is going to be one of the main needed resources for the cities' existence and the development of urban life - "is where the civilizations unroll happen". Beyond being the physical support for elements, flows and processes that give form, movement and life to cities, the ground must be served with a net of services, transportation infrastructure and several types of buildings so the urban activities can happen - "at this point the use and change values surge" (BAER, 2013, p. 221).

On property evaluation engineering, there are two central terms on discussions: value and price. Value is the monetary expression of a property. At the same time, price is the amount of cash needed to buy a property, being that by property we mean something that has a value, that can be used or become a thing with legal guarantees. In this context, there is a difference between market value, being this the more likely amount of money to be spent in a voluntary and conscious trade in a referenced data, following norms current in the market (ABNT, 2001) and, arbitrary value.

The last is obtained through property evaluation techniques to identify value, cost, produces and rights, together with viability indexes and its use for certain situations, goals and, dates, being the adopted value as the evaluation result, inside the limits established by the norms (15\% more or less) (ABNT, 2011). It concerns a group of variables and characteristics that compose a

\footnotetext{
${ }^{11}$ In Blumenau, De Paula (2015) says that the socio-spatial inequalities resulting from floods took the poor to displace themselves to the uphill, marked in this city by higher slopes and chances of mass movements events than Rio do Sul.
}

property, that when measured and added together, represents how much a property value, being a movable or immovable one. This, however, doesn't represent what necessarily is going to be paid in a trade, but how much the property value with its characteristics, considering location, benefits, or even the absences of it.

To this is added the venal value, being it an estimative gave by the public power that serves as reference for tax purposes. Also composed by its characteristics, is directly related to the generic values plant. This one is the basis for collection and calculation of taxes, as described by Silva (2006). As elements of the venal value, we spotlight position towards the street, area, building area, the property typology and, age (when it's relevant).

In terms of conceptualization, they are different nouns, even if used by common sense as synonyms. However, price means what is indeed paid for a property in a trade. So, it's not necessarily connected with the market value of a property, since that, considering the market dynamics, the will of both sides, together with the occasion needs, a property can be traded for thousands of dollars more or less beyond its value.

With this presentation, we worked with the real estate market data sample collected, focusing especially in data that expressed the properties' value, being that these contain some accountable attributes, with a spotlight to its geographical location. The methodology adopted follows the precepts stipulated by the ABNT $(2001,2011)$ norms and Silva's $(1999,2006)$ proposals. The NBR 14.653-1 (ABNT, 2001) norms predict the use of one out of four methods of property evaluation, being these: the involutive method; the evolutionary method; the income capitalization method; and the method base on direct comparison among the market's data. While we have followed the last, we are not going to value the properties, but to analyze the real estate market dynamics. We describe the data sample next.

The data sample collected is formed by 200 properties (only ground ones, without any building) on sale $^{12}$. We filtered only the announcement of terrain properties, as well as its characteristics (Picture 03). The sources were real estate agents (local and regional sized real estate offices ${ }^{13}$ ) and announcements found on aggregator websites like Zap Imóveis and OLX. The following variables were collected as the following picture shows.

\footnotetext{
12 The sampled data were collected remotely, using internet announcements (institutional or private ones).

${ }^{13}$ The agents are Dalfovo real estate office; San Genaro real estate office; Habiterra properties; Habivale real estate office; Carneiro properties; Charles Cimardi realtor; Metropolitana properties; and Pacher real estate office.
} 


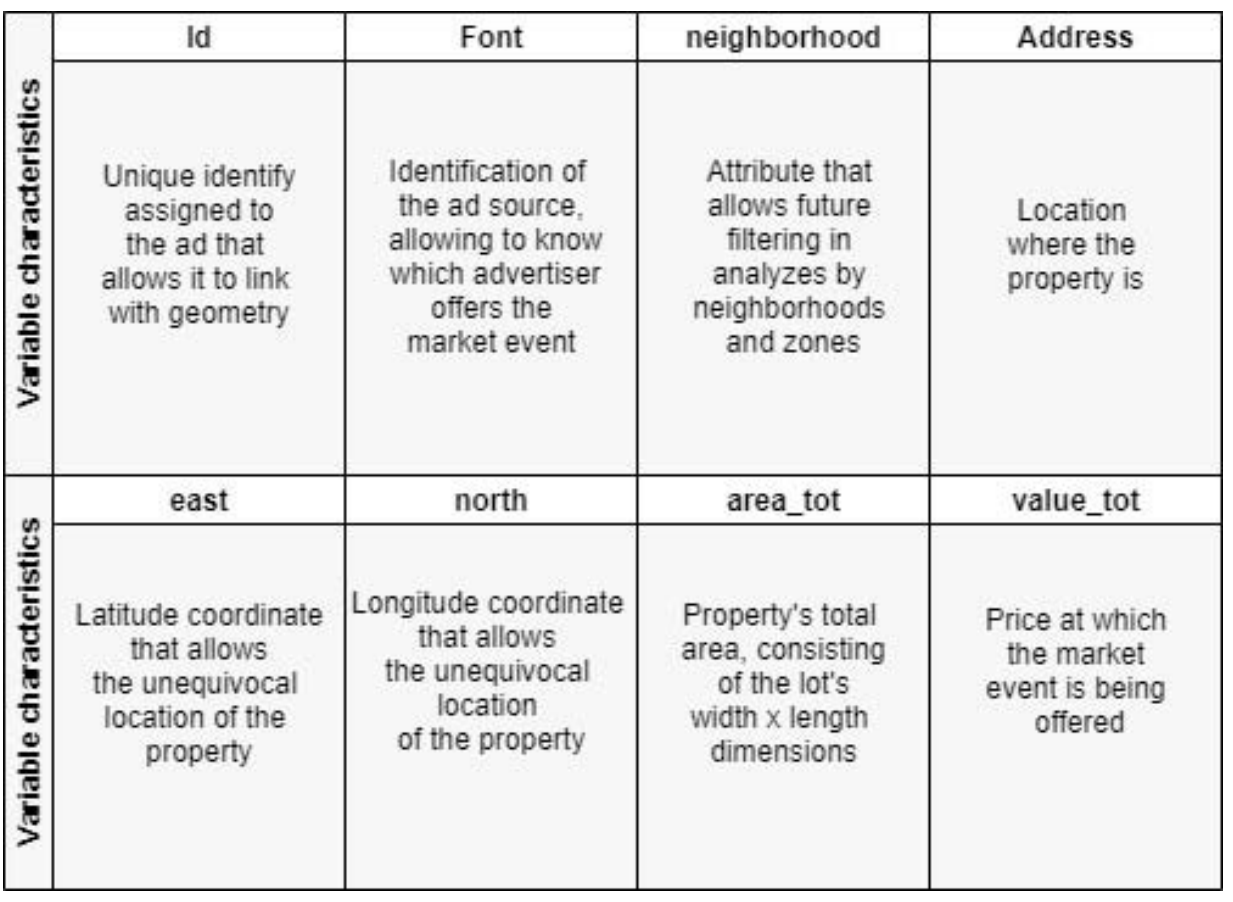

Source: By the authors

\section{Picture 03: Characteristics collected for every property}

When some essential characteristics for the data analysis couldn't be added to the list, the property got excluded.

\section{a) Materials used}

We used the following software as support tools for the data analysis: QGIS, on its 2.18.20 Las Palmas and 3.8.1 Zanzibar versions, open source software distributed by OSGeo; Google Earth Pro, 7.3.0 version, with free distribution by Google. For tabular data manipulation, we worked with Google Spreadsheets. At last instance, for the kriging applications together with the histometric analysis, we used SAGA, 2.1.3 version.

With the selling announcement data of the offered properties in the real estate office website and other sources, we prepared a spreadsheet with the data, with every case composed of eight columns. To every property, we gave a number as an identifier (id, as Picture 03). Then, geographical coordinates were included on the columns to include the properties on the Geographical Information System (GIS) for the geographical analysis.

We obtained the coordinates with the help of Google Earth Pro software, open to free access offered by Google. Searching for addresses available on the announcements, the software finds the property location, marking it on the map, then we gave it an id, crossing it with the spreadsheets. This identifier method allows the properties spatialization in a simplified manner.

The data analysis and also the cartographic products are from QGIS software application. This one has a simplified graphic interface for attributes edition, linking and, manipulation, chosen to the final print layout production. QGIS plugins permitted the use of base maps that allowed raster overlap from remote sensing images from Bing or Google Satellite. These base maps are used for map compositions manners and graphic support on the flood quotas analysis. The vector data about parcels, streets, neighborhoods, hydrology, and, floods shapes were provided by Rio do Sul's Municipal Chamber and it's Civil Defense, considering the scientific purpose of this research. 


\section{b) Method}

The data collection followed the activities flow presented on Picture 04, below.

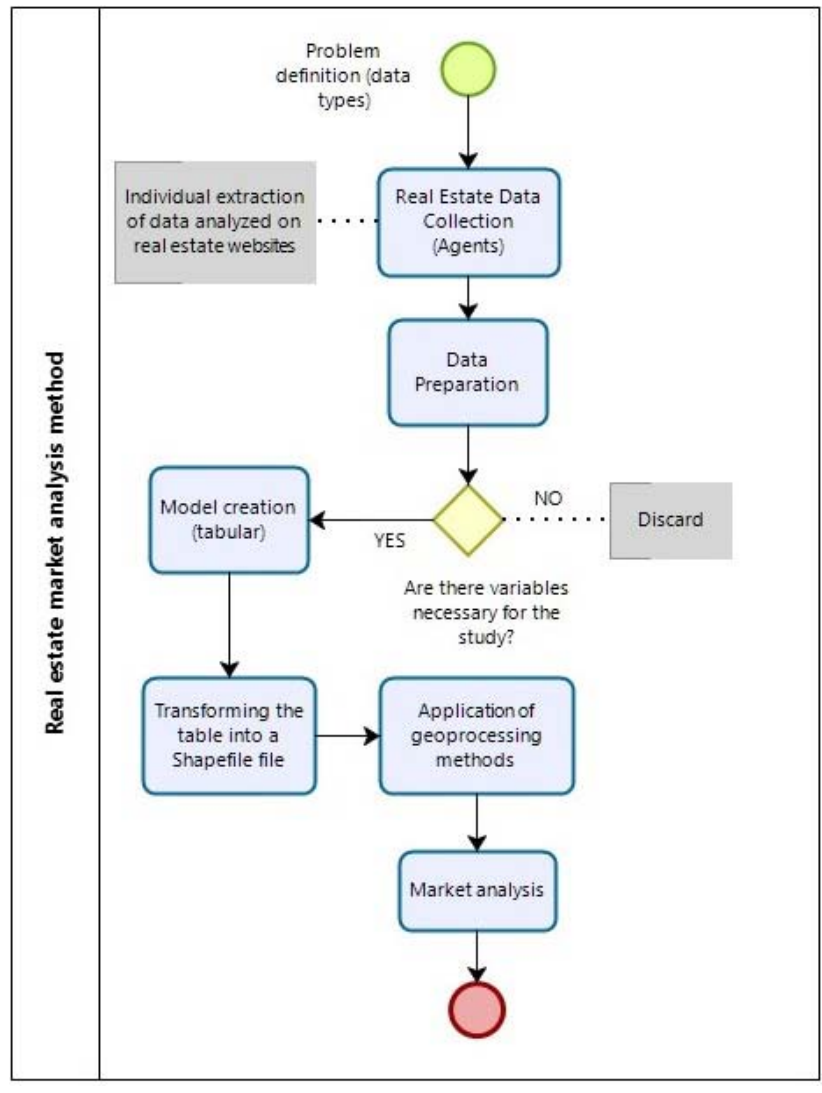

Source: By the authors

Picture 04: Activities flowchart

In the context of this flowchart application, we worked with the above-mentioned GIS software, characterized as geoprocessing tools that allow complex geographical analyses, crossing diverse data from $\mathrm{N}$ sources, including the creation of georeferenced databases (CAMARA et al., 2001). Today they offer different plugins that ease statistical analysis; among them, we can spotlight the important allowance of spreadsheets upload, like the Google ones. When a GIS software like QGIS, imports spreadsheets it is possible to interpret columns that can be of different types, like integer, date/time, string, and real (decimal numbers).

With the data collected and uploaded to QGIS we filtered them and proceeded to the analysis phase, focusing on obtaining a spatial product that could reflect the local real estate market dynamics. Then, we calculated the square meter $\left(\mathrm{m}^{2}\right)$ value through the division: sale value/total dimension for every property. This way we obtained the value for each property, comparing it to others between characteristics and geographic position.

So then it was possible to link the properties with the spreadsheets, crossing, merging and aggregating more than one table at a time. On the process of working with the properties price data, we ran validation tests, eliminating outliers, and preparing data for the last step of the analysis.

In this context, some concepts created by statistical scientists are useful for geographers in some research fields, where its methods allow the construction of visual layers from data samples together with geostatistics proceedings like kriging, which is helpful for associating uncertainty measures (CAMARA et al., 2001).

The graphical analysis that translates punctual data to raster can be done by different methods. The GIS application allows the projection of numerous hypothetical scenarios with some methods like closer neighbor, distance pattern, lines/areas length amounts, and kriging interpolation.

By kriging we mean a validgeostatistical method for finding a hypothetical value for the analyzed properties, been characterized as

(...) this method allows the interpolation of non-sampled variable values from sampled neighbors. The quota of some point of interest is calculated by the weighted average of the neighbor samples, determined by geoestatiscal analysis, which provides coefficients that describe the spatial variability of the analyzed data.

(VALERIANO, 2008, apud BRITO et. al., 2013) 
Kriging is based on the regionalized variables theory, having a polynomial equation in its fundamentals, through a multiple regression process between the properties market values and its locations (geographic coordinates). And this method has its divisions. There is the "simple kriging", in which the estimative are based upon an already known and constant average $(m)$ value. However, in the "ordinary kriging" there's no need for previous knowledge of the $m$ value.

Besides that, values obtained by "block kriging" are smoother than "punctual kriging", what made our choice for the first. So, for the error diminish, it is needed to use a $m$ number of samples. The vast application of the ordinary model can be explained by its simplicity (weighted average), which uses structural information provided by a variogram model, supplying de uncertainty connected to estimation (YAMAMOTO \& LANDIM, 2013).

To compare possible analysis methods, we know that in simple linear interpolation, the weights are all the same $(1 / N)$, defining in which the $N$ variable under the distance's square inverse that separates interpolated values and collected values. In kriging, the proceeding is close to the interpolation by weighted moving average, except that is this case, the defined weights come from spatial analysis. With this process, it provides non-biased estimations and with minimal variance. Therefore, the difference between kriging and other interpolation methods is the way how the samples receives its weights. Values obtained by this method in blocks are smoother than punctual ones (VALERIANO, 2008 apud BRITO et al., 2013), justifying its application for real estate market analysis.

The steps needed for a scientific work that applies kriging techniques, according to Druck et al. (2004), are (I) exploratory data analysis; (II) structural analysis (spatial correlation models); and (III) statistical surface interpolation. Thus, with QGIS support, we analyzed the collected values seeking outliers, very high or very low prices, with the sample distribution histogram. Following it, we proceeded to data filtering and outlier exclusion, seeking a better data distribution and homogenization, looking for higher quality in the analysis.

\section{c) Results obtained}

The properties' spatialization was created by GIS tools, allowing the different layers overlapping, with themes that describe some variables of Rio do Sul's urban elements. The following Picture (05) shows the overlapping between properties values with the flood quotas. They are divided into four classes, for analysis purposes: 7 meters quota ${ }^{14}$; 9-9.50 ${ }^{15}$ meters; 10.71 meters (from the 2015 floods); and 13.56 meters (from the historical record of 1983), being these measured from the riverbed.

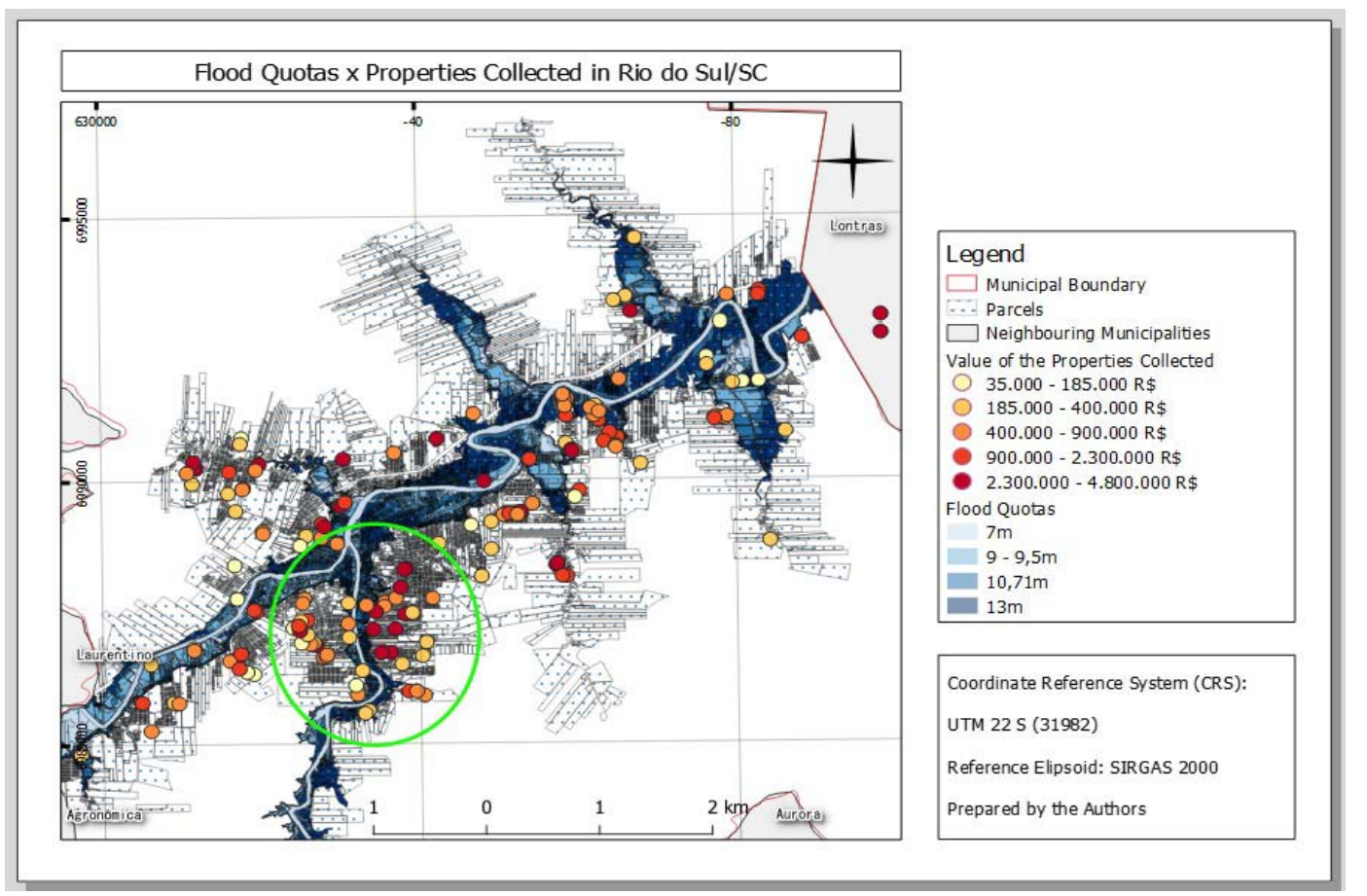

Source: By the authors

\section{Picture 05: Overlapping of collected properties with flood quotas ${ }^{16}$}

\footnotetext{
${ }^{14}$ According to Bogo (2019), this quota has the most frequent flood occurring, tending to reach low-income populations, in most cases attached to the "informal city".

${ }^{15}$ From PMRS (2019) data, it's one of the most frequent flood quotas.

${ }^{16}$ For interpretation purposes, every Brazilian Real (R\$) equals 0.2 US Dollar (US\$). This exchange rate must be read through the rest of the paper.
} 
Seeking a better visualization, we generated a group of maps that show the areas reached for each class, together with the properties and value distribution. The following Picture 06 shows this information. Through the collected properties, we can identify more density of high-value ones (classes with darker tons and marked in the map inside the green circle) on the central region, especially in Centro, Jardim América, and Sumaré neighborhoods, including some of flood reachable ones. In the maps that form the picture, it is possible to see the unitary flood classes.

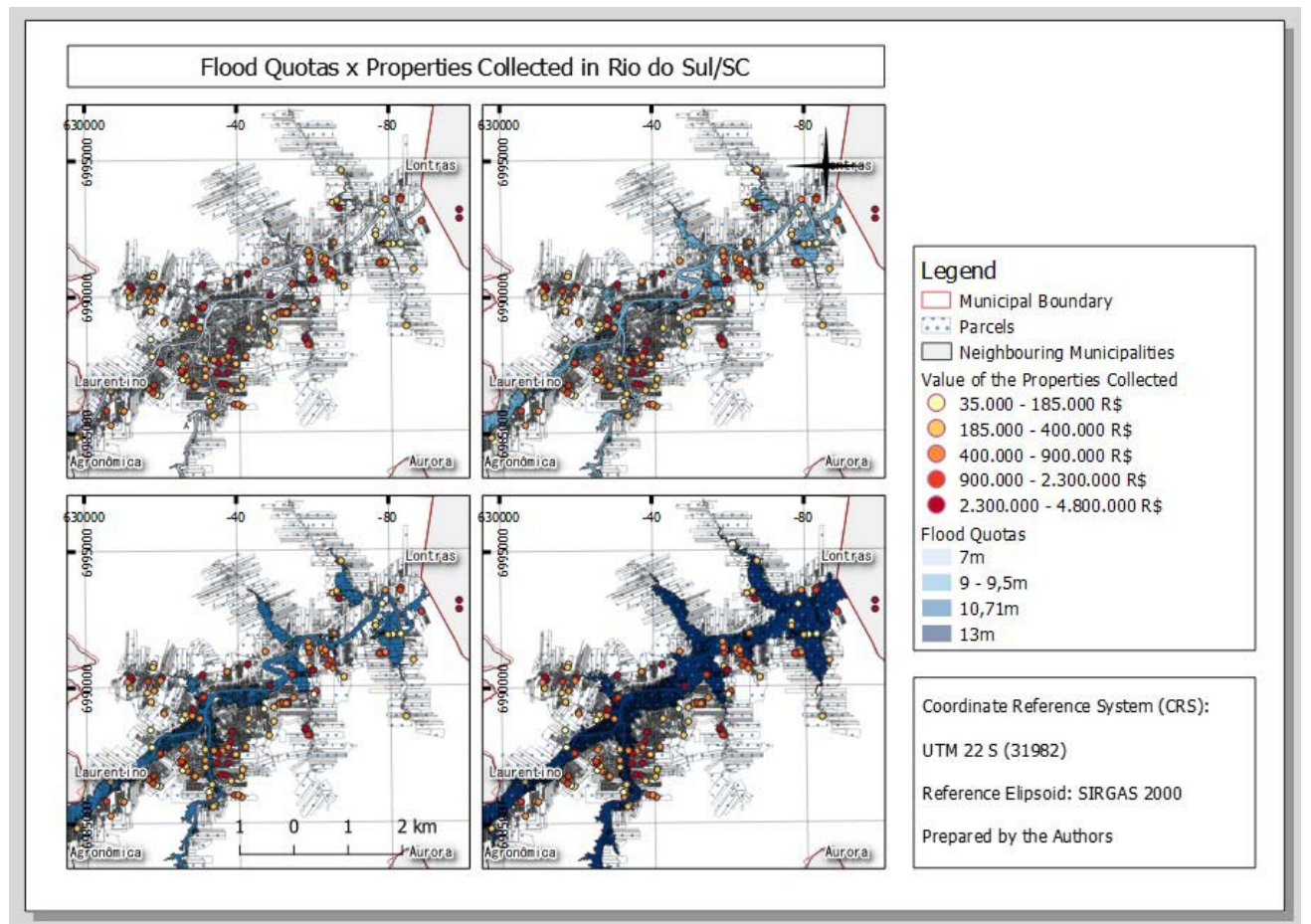

Source: By the authors

Picture 06: Unitary flood quotas, overlapped with the properties collected

Applying SAGA's software tools, it was crafted an interpolation between properties values and its $\mathrm{m}^{2}$ values, from the ordinary kriging method, focusing on data distribution analysis. The results are available in Picture 07.

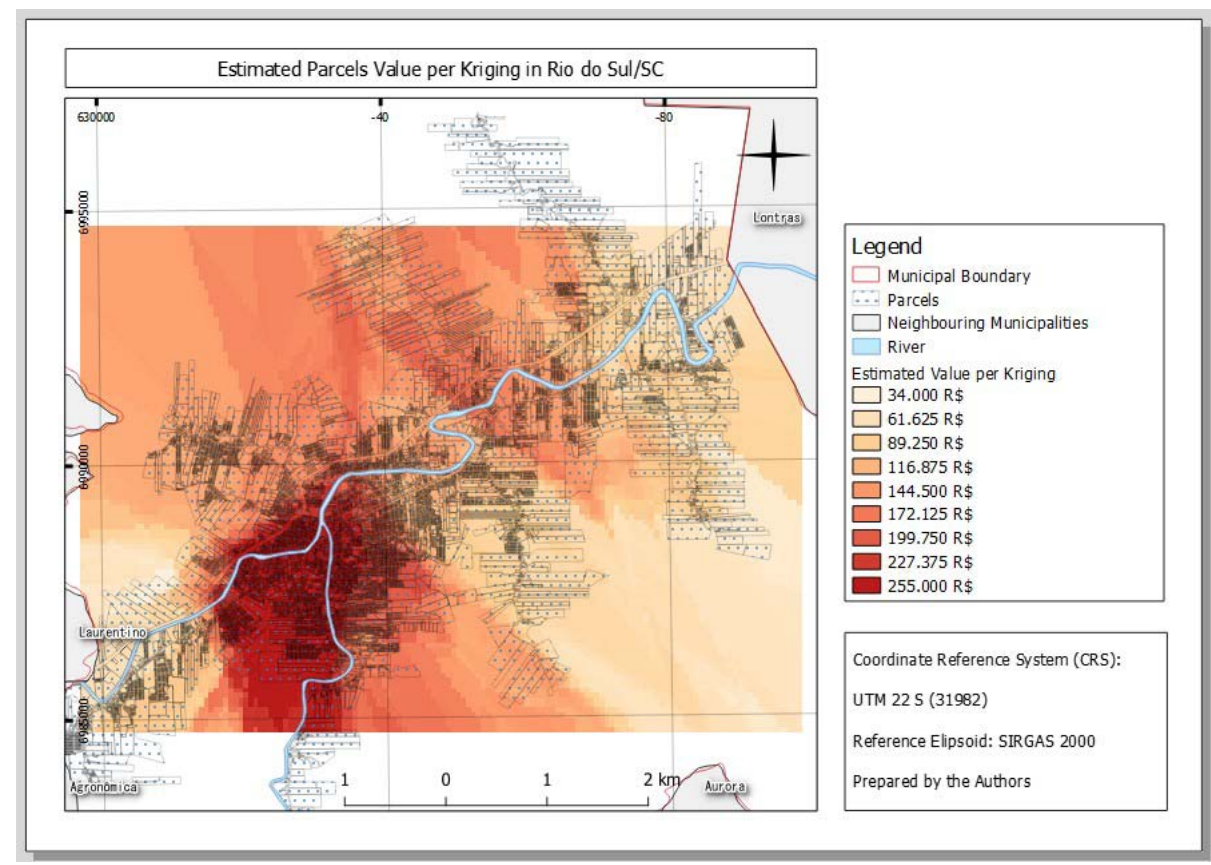

Source: By the authors

Picture 07: Total value variable kriging results 
In the analysis, properties over 2,500 $\mathrm{m}^{2}$ (26 cases) and prices over $\mathrm{R} \$ 350.000$ were discarded, which could show distortions in the results, setting the already mentioned outliers. Therefore, 152 properties served for the total value kriging process. The resulting values histograms can be seen, in sequence, in the Pictures 08 and 09.

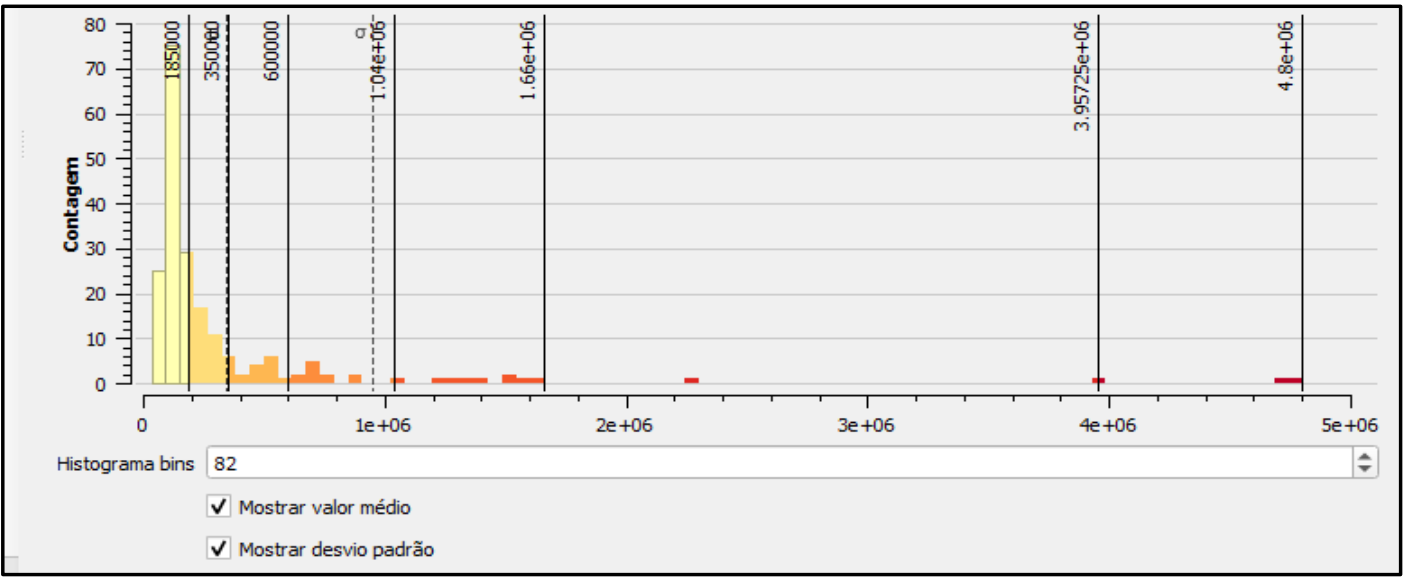

Source: By the authors

Picture 08: Histogram before data filtering

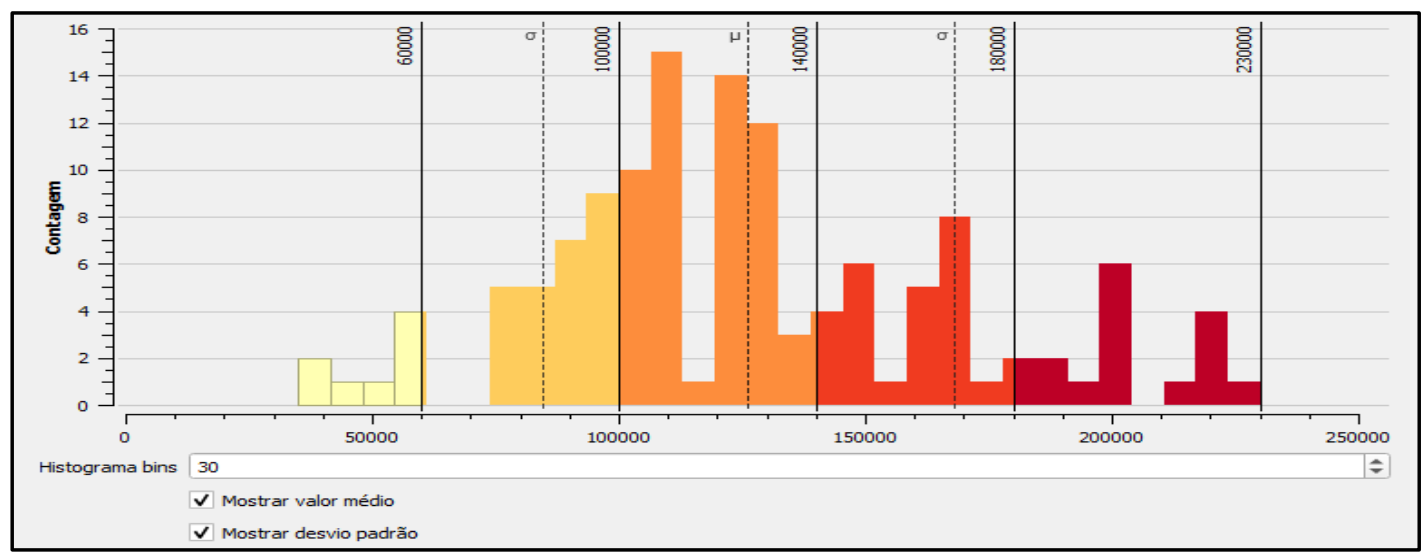

filtering Source: By the authors

Picture 09: Histogram after outliers

The sample basis for the average $\mathrm{m}^{2}$ value and respecting the NBR 14653-1 and NBR 14653-2 kriging didn't have the problem of few cases because of the 200 properties only 36 were discarded, with 164 norms (ABNT, 2001; 2011). The variogram is available in used for the final analysis, respecting the minimal limit Picture 10.

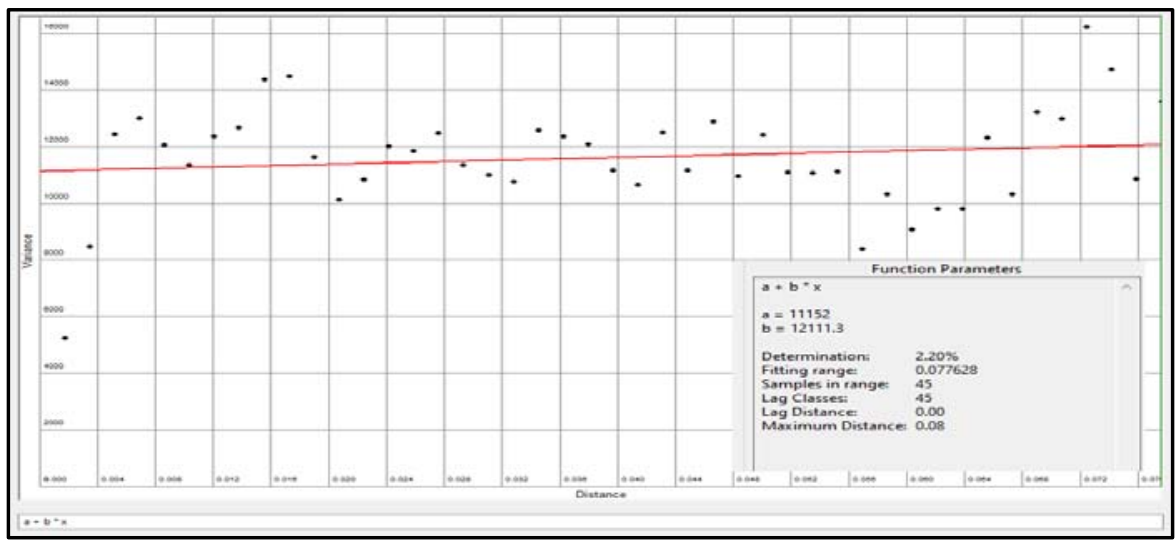

Source: By the authors

Picture 10: Kriging variogram of the average $\mathrm{m}^{2}$ value 
With the kriging done, QGIS and its plugins served as tools to the process of extrapolating the pixel values (in $\mathrm{m}^{2}$ ) for the lots (parcels) polygons. We adopted the square meter $\left(\mathrm{m}^{2}\right)$ as variable to this research step based upon that the total values can present some distortions since the price of a property is composed of various characteristics. That heterogeneity is an inherent factor to the real estate market analysis. In this sense, the estimated $\mathrm{m}^{2}$ value based on the samples showed itself as the suited alternative for the analysis.

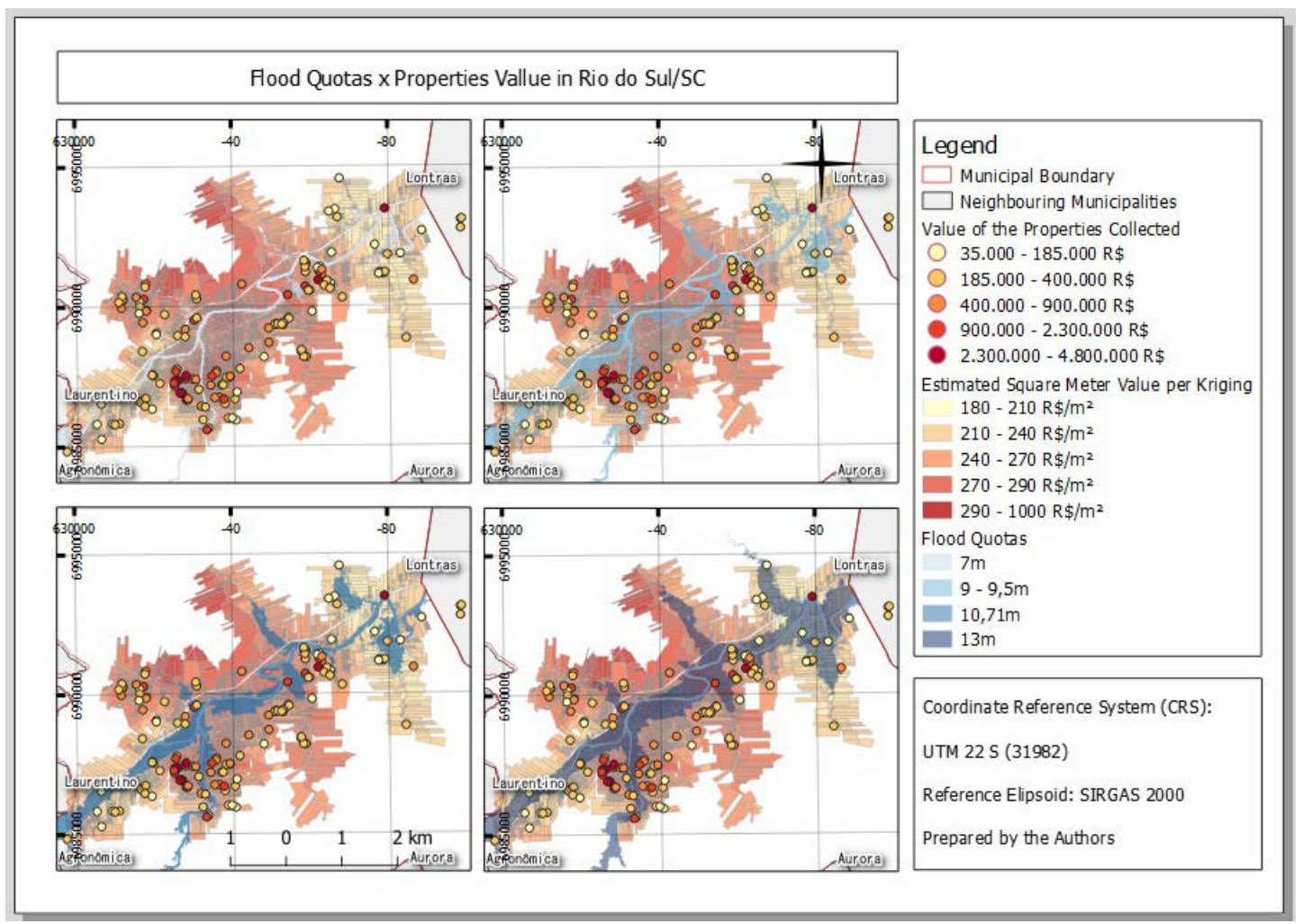

Source: By the authors

Picture 11: Correlation between separated flood quotas and properties values and 12) were made, with the $\mathrm{m}^{2}$ value extrapolated to the lots and with the punctual collected data, both overlapped with the floods layers (respectively separated and together), seeking to identify from the spatial analysis if the flood quotas influence in the properties averages $\mathrm{m}^{2}$ value and if in some way the prices change for being located in areas reached by floods (or if they are free of them), influencing the local socio-spatial segregation. 


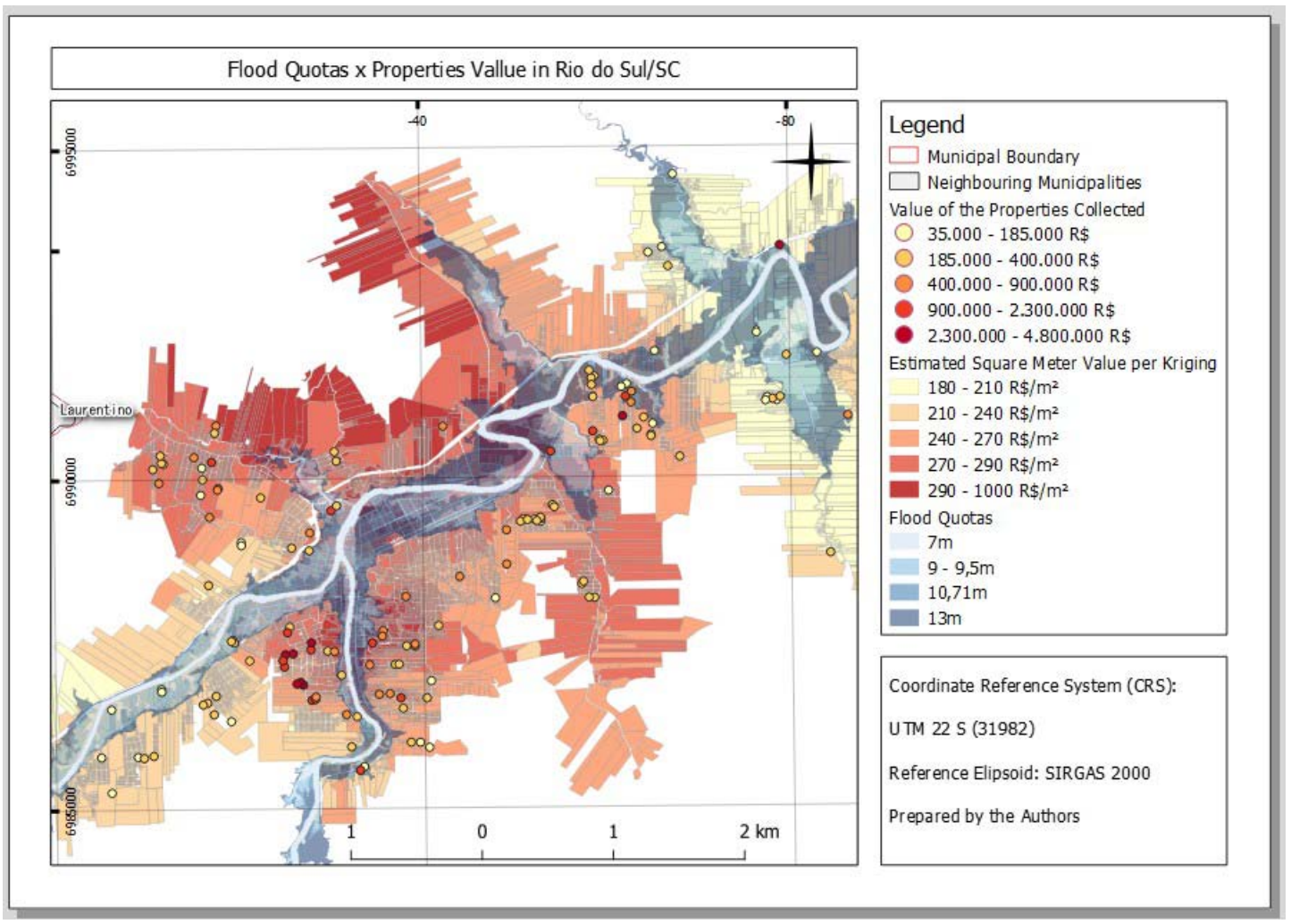

Source: By the authors

Picture 12: Correlation between overlapped flood quotas and properties values

Even if we consider that the maps above are our last product and are also self-explicative, a brief analysis is needed to help our comprehension before the final remarks.

What the pictures 11 and 12 show are two clear tendencies. The first one is about the fact that there is a strong property evaluation tendency as a result of its relationship with the central area, pointing that the more distant neighborhoods (Santa Rita, Rainha, Barragem, Barra do Trombudo, among others), both to the northeast or southwest, contain most of the lower market value properties collected. In these cases, the lower classes presented in the maps, containing $\mathrm{m}^{2}$ values between $R \$ 180$ to $R \$ 240$, prevail among these areas samples and in the estimations after them.

Thus, it is possible to see about higher value classes is the prevalence of it around the city center, including neighborhoods like Centro, Jardim América, Sumaré, and Eugênio Schneider. The collected points and the extrapolation related to that are between $\mathrm{R} \$ 270$ to $R \$ 1,000$ per $m^{2}$ are found only in these regions, what can be understood as evidence of how the "structural urban node" that formed already in the 1950 decade (COLAÇO \& KLANOVICZ, 1999) still being the major focus of the services private market and the city's amenities aggregator, raising the prices of the available terrain properties on its surroundings.

The second tendency involve this research's objective, being the values relations with floods. What can be seen from the graphic products is that there is relevant evidence that the floods have an influence on real estate market prices, with the spotlight to where the waters hit more often. It is possible to assume that because some of the most valuable properties collected are reached just by the higher quota ever (from 1983) and not by the others. Besides that, not just only the investigation identified that the most valuable $\mathrm{m}^{2}$ (and its extrapolations) are in general located close to the city's center and free from floods, in areas where the public power supports long term urbanization (BOGO, 2016; 2020), but also how the lower prices can be seen especially in farther neighborhoods that are hit by the waters, including the ones that happen more often.

So, what we can understand is that the real estate market values (and prices) are guided by the following "equations": free from floods + close to city center = higher prices; reached by floods + away from the city center $=$ lower prices. So, there is a tendency of intensification of the current socio-spatial segregation because of this phenomenon.

However, the research doesn't entirely confirm the affirmations from Colaço \& Klanovicz (1999) and Espíndola \& Nodari (2015), as the floods aren't the only factor to influence the real estate market prices and dynamics. The central neighborhoods, due to its access to services, amenities and better infrastructure are still responsible for properties' high evaluation, making residents and, shop owners to continue dealing with the 
floods, not being responsible for such an intense displacement of local activities as the authors argue. But, we consider that we have hit some methodological limits considering that the lower areas on the central neighborhoods as well as on the "informal city" cases tend to have a higher number of buildings (so, lower terrain properties available), that aren't included in this scientific investigation, what is again discussed in the following final remarks.

\section{FINAL REMARKS}

After the application of the methods presented on this research (geoprocessing techniques together with kriging), we ascertained some spatial correlations about the real estate market values concerning its spatial locations, being reached by floods or not, concluding that this factor has territorial relevancy. However, it is not the only and excluding variable on this matter.

Especially in areas that are reached by 7 and 9 meters' floods, in other words, areas that the river waters hit more often, we identified the decrease of propertiy values. But, this factor is not so relevant in the city center and its close neighborhoods, with the spotlight to Jardim América, Centro, Sumaré and, Eugênio Schneider. From these findings, we believe that this phenomenon occurs because the central region hasan urban core of complex nature, centering in it the most important commercial structures, businesses, among others, causing consequences on the tendencies of properties evaluation.

Therefore, this causes some kind of partial "neutralization" of floods risk influence, considering the characteristics marked on this case of study. Oppositely, the neighborhoods located in floodable areas that are also far away from the city center present a deeper tendency of properties devaluation when these are reached by the waters.

That is, in a first general analysis: (I) it is possible to understand that the altitude factor - that reflects in less flood risk in comparison with lower areas - demonstrated itself as a relevant factor to variations among the properties prices in Rio do Sul; (II) About the neighborhoods centrality - regarding its connection with better infrastructures and more services available presents itself as a variable that guides a small "neutrality" of the cause-effect relation between floods and properties prices.

Considering the maps made, they show these variations through the city's territory, deepening the evidence about the floods influence in real estate market dynamics, also on the central region, where the highest prices are seen in floods free places.

Partially, the attributes that appear as more relevant in the analysis are the degree of "centrality" and "flood risk". A critical analysis together with the historical descriptions and field knowledge showed that the above-mentioned variables influence a possible fragmentation among economic classes in Rio do Sul's socio-spatial dynamics, considering that the properties with the highest prices, both close and far from the city center, seem more protected to floodable areas.

The case of study object complexity suggests that the research and its methods attended its expectations and brought information to craft others and more complex discussions about this territory. From that, other scientific investigations can take advantage of this "window of opportunity" to identify and analyze which other variables could complement the correlations between properties value/price on this regions, collecting data, for example, of rent prices, buildings for sale or real estate market prices for already built places. These variables could complement the current analysis from the method presented here and expand the comprehension about the territorial transformations of Rio do Sul municipality, also opening new interpretations about the acts of its spatial agents.

Therefore, the affirmative that "how higher the flood risk, the lower the property values" showed itself partially correct, considering that the variable "urban centrality" have relevant influence in prices, making that the cause-effect relation of the floods devaluating the properties raised on the hypothesis before is not entirely true, even that we identified that most of the expensive properties are located in areas free from the river waters. But, specifically in the cases of the distant neighborhoods the premise above was confirmed as true. However, we believe that the research's central problem isn't entirely resolved and new scientific investigations, using other variables together with flood studies must be done, seeking for the confirmation or refutation of the hypothesis proposed here.

\section{AbBreviations}

ABNT- Associação Brasileira de Normas Técnicas (Brazilian Association of Technical Norms)

\section{GIS - Geographiclnformation Systems}

IBGE - Instituto Brasileiro de Geografia e Estatística (Brazilian Institute of Geography and Statistics)

PMP - Participatory Master Plan

PMRS - Prefeitura Municipal de Rio do Sul (Rio do Sul's Municipal Chamber)

SC - Santa Catarina state

\section{References Références Referencias}

1. ASSOCIAÇÃO BRASILEIRA DE NORMAS TÉCNICAS - ABNT (2001). NBR-14653-1. Avaliação de Bens - Parte 1: procedimentos gerais.

2. ASSOCIAÇÃO BRASILEIRA DE NORMAS TÉCNICAS - ABNT (2011). NBR-14653-2. Avaliação de Bens - Parte 2: imóveis urbanos. 
3. BAER, L. (2013). Principios de economía urbana y mercados de suelo. in: ERBA, Diego Alfonso (Org.), Definición de políticas de suelo urbano en América Latina: teoría y práctica. Viçosa, MG. 2013. 283 p.

4. BOGO, R. S. (2016). Plano diretor participativo, território e inundações em Rio do Sul/SC. Trabalho de conclusão de curso. Florianópolis. Departamento de Geociências, Universidade Federal de Santa Catarina.

5. BOGO, R. S. (2019). Impacto das inundações de 7 metros em Rio do Sul/SC: o Plano Diretor Participativo como objeto de análise. Rio do Sul: Nossa História em Revista, Rio do Sul, 23 (6), pp. 07-31.

6. BOGO, R. S. (2020). Participatory master plan, territory and floods in Rio do Sul/State of Santa Catarina. Cadernos da Metrópole, São Paulo, 22 (48), pp. 555-577. Disponível em: https://revistas. pucsp.br/metropole/article/view/2236-9996.20204810/pdf e. Acesso em: 29 jun. 2020.

7. BRASIL (2001). Law n. 10257, July 10th, 2001. Regulate the articles 182 and 183 of the Federal Constitution, stablishes general directions of the urban politics and gives other measures. Estatuto da Cidade. Brasília, Availableat: <http://www. planalto. gov.br/Ccivil 03/leis/LEIS 2001/L10257.htm>.

Access in: Aug 2nd 2018.

8. BRITO, C. R. et al (2013). Geoestatística aplicada na geração de modelos numéricos de elevação. Geografia Ensino \& Pesquisa, 17 (3), pp. 143-152.

9. COLAÇO, T. L.; KLANOVICZ, J. (1999). "Urbanização". In: KLUG, J.; DIRKSEN, V. Rio do Sul: uma história. Rio do Sul, Editora da UFSC. Cap. 3. pp. 121-149.

10. CORRÊA, Roberto L. (1986). Espaço Urbano. 1 ed. Rio de Janeiro, Ática.

11. DE PAULA, S. M. (2015). As enchentes em Blumenau: um desastre anunciado. In: NODARI, E. S.; ESPÍNDOLA, M. A.; LOPES, A. R. S. (org.). Desastres Socioambientais em Santa Catarina. São Leopoldo: Oikos. pp. 52-67.

12. DRUCK, S. et al [eds.] (2004). Análise Espacial de Dados Geográficos. Brasília, EMBRAPA.

13. ESPÍNDOLA, M. A.; NODARI, E. S. (2015). Desastres surpreendentes: enchentes rotineiras. In: NODARI, E. S.; ESPÍNDOLA, M. A.; LOPES, A. R. S. (org.). Desastres Socioambientais em Santa Catarina. São Leopoldo: Oikos. pp. 68-94.

14. GOULARTI FILHO, A (2014). Portos, Ferrovias e Navegação em Santa Catarina. Florianópolis: Editora UFSC. 322 pp.

15. GRANGEIRO, E. L. de A.; RIBEIRO, M. M. R.; MIRANDA, L. I. B. de (2020). Integração de políticas públicas no Brasil: o caso dos setores de recursos hídricos, urbano e saneamento. Cadernos da Metrópole, São Paulo, 22 (48), pp. 417-434. Disponível em: https://revistas.pucsp.br/metropole/ article/view/2236-9996.2020-4804. Acesso em 29 jun. 2020.

16. INSTITUTO BRASILEIRO DE GEOGRAFIA E ESTATÍSTICA - IBGE (2019). Santa Catarina. Disponível em: https://cidades.ibge.gov.br/brasil/ sc/panorama. Acesso em: 30 jun. 2020.

17. INSTITUTO BRASILEIRO DE GEOGRAFIA E ESTATÍSTICA - IBGE (2020). Região de Influência das Cidades 2018. Brasília: IBGE 187 pp. Disponível em: https://www.ibge.gov.br/geociencias/cartas-emapas/redes-geograficas/15798-regioes-deinfluencia-das-cidades. html? =\&t=acesso-aoproduto. Acesso em: 29 jun. 2020.

18. LAPOLLI, Aderbal Vicente (2013). O Plano diretor e o plano de gerenciamento de enchentes do município de Rio do Sul - SC:A construção de um território seguro? Dissertação de mestrado. Florianópolis, Centro de Ciências Humanas e da Educação, Universidade do Estado de Santa Catarina.

19. MAAR, A., PERON, A., \& NETTO, F. D. (2011). Santa Catarina: História, espac,ogeográfico e meio ambiente (2nd ed.). Florianópolis, SC: Insular.

20. MASSEY, D. (2005). For Space. London: Sage Publications. $232 \mathrm{pp}$.

21. MASSEY, D. (2017). A mente geográfica. Geographia, Niterói, 19 (40), pp. 36-40. Traduzido por Ana Angelita da Rocha e Maria Lucia de Oliveira. Disponível em: https://periodicos.uff.br/ geographia/article/view/13798/8998. Acesso em: 30 jun. 2020.

22. NODARI, E. S.; ESPÍNDOLA, M. A.; LOPES, A. R. S. [org.] (2015). Desastres Socioambientais em Santa Catarina. São Leopoldo: Oikos, 302 pp.

23. POLEZA, Maristela Macedo (2003). Mudanças na estrutura urbana de Rio do Sul em decorrência das enchentes de 1983. Dissertação de mestrado. Blumenau, Universidade Regional de Blumenau.

24. PREFEITURA MUNICIPAL DE RIO DO SUL - PMRS (2019). Quadro de cheias ocorridas em Rio do Sul.Available at: <https://defesacivil.riodosul.sc. gov.br/index.php?r=externo\%2Fplanilha $>$. Access in: Oct 5th 2019.

25. SANTA CATARINA [Gabinete de Planejamento e Coordenação Geral] (1986). Atlas de Santa Catarina. Rio de Janeiro, Aerofoto Cruzeiro. 173 p. SANTOS, M. (2013). A Urbanização Brasileira. 5. ed. São Paulo: Edusp, $174 \mathrm{p}$.

26. SANTOS JÚNIOR, O. A. dos; MONTANDON, D. T. [Org.] (2011). Os Planos Diretores Municipais PósEstatuto da Cidade: balanço crítico e pespectivas. Rio de Janeiro, Letra Capital. 295 pp.

27. SIEBERT, C. F. (1997). Estrutura e desenvo/vimento da Rede Urbana do Vale do Itajaí.Blumenau, Editora da FURB. $118 \mathrm{p}$.

28. SILVA, E. (2006). Cadastro Técnico Multifinalitário: base fundamental para Avaliação em Massa de 
Imóveis. Tese de Doutorado em Engenharia de Produção. UFSC. 201 pp.

29. SILVA, E. (1999). Proposta de avaliação coletiva de imóveis: aplicação aos imóveis do tipo apartamento na cidade de Blumenau - Santa Catarina. Florianópolis. Dissertação de Mestrado em Engenharia Civil. UFSC. 95 pp.

30. SOUZA, M. L. de (2006). A Prisão e a Ágora: reflexões em torno da democratização do planejamento e da gestão das cidades. Rio de Janeiro: Bertrand Brasil. 632 pp.

31. SOUZA, M. L. de (2010). Mudar a cidade: uma introdução crítica ao planejamento e à gestão urbanos. 6. ed. Rio de Janeiro, Bertrand Brasil. $556 \mathrm{pp}$.

32. TUCCI, C. E. M. (2007). Inundações urbanas. Porto Alegre, ABRH/RHAMA. 393 pp.

33. VILLAÇA, F. (1999). Uma contribuição para a história do planejamento urbano no Brasil. In: DEÁK, C.; SCHIFFER, S. R. (Org.). O processo de urbanização do Brasil. São Paulo: Edusp. Cap. 6. pp. 169-243.

34. YAMAMOTO, J.K.; LANDIM, P.M.B (2013). Geoestatística: conceitos e aplicações. São Paulo, Oficina de Textos. 215 p. 